\title{
FORAGE FAUNA IN THE DIET OF BIGEYE TUNA (Thunnus obesus) IN THE WESTERN TROPICAL ATLANTIC OCEAN
}

\author{
Teodoro Vaske Júnior*, Paulo Eurico Travassos, Fábio Hissa Vieira Hazin, \\ Mariana Travassos Tolotti and Taciana Martins Barbosa
}

\author{
Universidade Federal Rural de Pernambuco \\ LEMAR, Departamento de Pesca e Aquicultura
}

(Av. Dom Manuel de Medeiros s/n, 52171-900 Recife, PE, Brasil)

*Corresponding author: vaske@ig.com.br

\begin{abstract}
A B S T R A C T
A total of 291 stomachs of bigeye tuna caught in the Western tropical Atlantic Ocean ranging between 60 and $195 \mathrm{~cm}$ fork length, were analyzed between October 2004 and November 2005. The vertical distribution of prey was studied in relation to their feeding strategies. A total of 83 prey items were identified of which 46 were fishes, represented mainly by brephoepipelagic, and mesobathypelagic fishes; 20 cephalopods, 13 pelagic crustaceans, one tunicate, one heteropod and one pteropod. The Caribbean pomfret Brama caribbea was the most important food item, followed by other mesopelagic fishes such as Alepisaurus ferox, Omosudis lowei, Gempylus serpens, Brama brama and Diretmus argenteus. The squid Ornithoteuthis antillarum was the main preyed-on cephalopod, and the crustaceans Caridea and Brachyuran megalopae were also important food items. The feeding may occur continuously, all the time, or at least during the greater part of the day or night, as part of the feeding strategy to prey upon a vertically scattered small prey distributed in the water column. The relative equality in the proportions of surface, mid-water and deep-water prey organisms reflects the behavior of constant vertical displacement in the search for prey. Although the bigeye tuna prefers subthermocline layers, most of its prey items perform diel migrations and can be preyed on both near the surface and in deeper waters.
\end{abstract}

\section{RESUMO}

Um total de 291 estômagos de albacoras-bandolins capturadas no oceano Atlântico tropical oeste variando entre 60 e $195 \mathrm{~cm}$ de comprimento furcal, foram analisados entre outubro de 2004 e dezembro de 2005. A distribuição vertical das presas foi estudada em relação às estratégias alimentares. Um total de 83 itens alimentares foi identificado dos quais 46 foram peixes representados principalmente por peixes brefoepipelágicos e mesopelágicos, 20 cefalópodes, 13 crustáceos pelágicos, um tunicado, um heterópode e um pterópode. A palombeta-do-Caribe, Brama caribbea, foi o item alimentar mais importante, seguida de outros peixes mesopelágicos como Alepisaurus ferox, Omosudis lowei, Gempylus serpens, Brama brama e Diretmus argenteus. A lula Ornithoteuthis antillarum foi o principal cefalópode predado, e os crustáceos Caridea e megalopas de Brachyura também foram itens importantes. A alimentação deve ocorrer de forma contínua, toda hora, ou pelo menos durante a maior parte do dia ou da noite, como parte da estratégia de predar sobre presas espalhadas na coluna d'água. A relativa equitabilidade de proporções de organismos de superfície, meia-água e água profunda na dieta refletem um comportamento de constante deslocamento vertical a procura de presas. Embora a albacora-bandolim prefira camadas subtermoclinais, a maioria de suas presas realiza migrações verticais diárias e podem então, serem predadas tanto próximas à superfície como em águas mais profundas.

Descriptors: Bigeye tuna, Micronekton, Pelagic.

Descritores: Albacora-bandolim, Micronécton, Pelágico.

\section{INTRODUCTION}

The bigeye tuna, Thunnus obesus, is distributed in all the tropical and subtropical oceans, occurring between $50^{\circ} \mathrm{N}$ and $45^{\circ} \mathrm{S}$ in the Atlantic Ocean (COLLETTE; NAUEN, 1983). Juvenile specimens under $50 \mathrm{~cm}$ total lenght are found near the surface and are caught mainly by purse seine and handline with mixed shoals of yellowfin tuna (Thunnus albacares) and skipjack tuna (Katsuwonus pelamis). Adult specimens are caught mainly by longline in deep waters, at more than 300 meters 
depth, in tropical areas. At the present time, the International Commission for the Conservation of Atlantic Tunas (ICCAT) considers it a stock unique to the Atlantic Ocean (ICCAT, 2006). The main commercial catches of longliners occurs in the first semester of the year in the central Atlantic (between $15^{\circ} \mathrm{N}$ and $10^{\circ} \mathrm{S}$ ), where the CPUE (Catch per Unit of Effort) ranges between 0.35 and 0.90 individuals per 1000 hooks (HAZIN et al., 1998; EVANGELISTA et al., 1998).

The adult bigeye tuna is known as a deep water and subthermocline species. However, studies on vertical distribution made by acoustic telemetry, have demonstrated that bigeye tuna usually exibit a "successive U" vertical movement pattern, staying in deep water during the daytime and near the surface at night, as part of their physiological or biotic strategy (HOLLAND et al., 1992; BRILL et al., 1999; DAGORN et al., 2000; BERTRAND et al., 2002; BACH et al., 2003; MUSYL et al., 2003). The reduced food availability for tuna in tropical pelagic environments seems relative as studies have demonstrated that the ecophysiological capacity of tuna in terms of vertical displacement allows them to prey upon different prey resources from the surface down to $600 \mathrm{~m}$, with vertical differences in water temperature of more than $20^{\circ} \mathrm{C}$ (MUSYL et al., 2003).

Studies on the feeding of bigeye tuna in the

Atlantic have so far been restricted to faunistic lists of prey (DRAGOVICH, 1969; MATTHEWS et al., 1977; ZAVALA-CAMIN, 1978) and trophic relationships with other pelagic predators. However, little scientific research has been undertaken into the feeding strategies associated with their vertical movement pattern. Some of the distributional patterns shown by the CPUE and weight indices of bigeye tuna in the Indian Ocean have been similar to those found in the Pacific Ocean, nevertheless, the lack of information on the distribution of their food resources has been an important factor in the limitation of our understanding of bigeye tuna in the Indian Ocean (LEE et al., 2005).

If it is considered that large pelagic predators such as tuna are efficient biological samplers for the collection of information on micronektonic fauna, then it may be expected that the forage fauna of the bigeye tuna should be composed mainly of subthermocline organisms consisting primarily of non diel migrant organisms. If, however, they feed continuously during both day and night throughout their vertical displacement, the proportions of surface, mid-water, and deep-water prey organisms in their forage fauna might be expected to be much more similar. The aim of this study was therefore to test this hypothesis by identifying the kinds of organism which are important in number, weight, and frequency of occurrence, preypredator relationships, and feeding strategies, in the western tropical Atlantic and determine whether the larger proportion of prey organisms consists in fact of subthermocline species for the large bigeye tuna from the longline fishery.

\section{Material and Methods}

The study area is located in the western tropical Atlantic, in which sampling was carried out between October 2004 and November 2005 by observers on board commercial tuna boats that operate longlines with hook-depths of between 50 and $300 \mathrm{~m}$, based in Natal and Recife (Northeastern Brazil) (Fig. 1). A total of 291 stomachs of bigeye tuna caught in this area were analyzed. The stomachs were removed and stored frozen onboard and each specimen's respective fork length $(\mathrm{cm})$ and position and date of catch recorded. In the laboratory the stomachs were thawed out and opened and the prey organisms found sifted in a 1-mm mesh sieve. The prey items were identified to the lowest possible taxon in accordance with the specialized literature or specialist guidance. The number of specimens of each food item found in each stomach was recorded as also the mantle length of cephalopods, the total length of other organisms and the wet weight of each prey item. Bait used by longliners consisted of mackerel (Scomber japonicus) and squid (Illex argentinus) and these were omitted from the analysis when found in the stomachs. Lengths were measured to the nearest centimeter, and weight in grams. A prey-accumulation curve was constructed to determine whether the sample size was sufficient (CORTÉS, 1997).

Prey were classified, in a general vertical distribution as Non-Migrant Surface (S) (0-200 m), Mid-Water Migrant (M) (0-1200 m), and Non-Migrant Deep-Water (D) (500-1000 m), in accordance with the surveys undertaken by Legand et al. (1972), Bowman and Gruner (1973), Roper and Young (1975), Smith and Heemstra (1986) and Bertrand et al. (2002).

Stomach fullness was recorded according to a five-point scale of estimated percentages of total fullness: empty, $25 \%$ full, $50 \%$ full, $75 \%$ full and full. Empty stomachs were excluded from the analysis.

The importance of each food item in the diet was gauged by the Index of Relative Importance (IRI) (PINKAS et al. 1971), modified according to weight as follows: $\mathrm{IRI}=\% \mathrm{FO} \times(\% \mathrm{~N} \times \% \mathrm{~W})$, where: $\% \mathrm{FO}$ is the relative frequency of occurrence of each food item, $\% \mathrm{~N}$ the proportion in prey number of each item in the total stomach content, and $\% \mathrm{~W}$ the proportion by weight of each item in the total content.

Occurrence of otoliths and isolated cephalopod beaks, i.e., with no flesh on the wings, was not considered in the IRI calculation to avoid the overestimation of the importance of fish and cephalopods in the diet due to their accumulation in the stomachs (VASKE; RINCÓN 1998). 


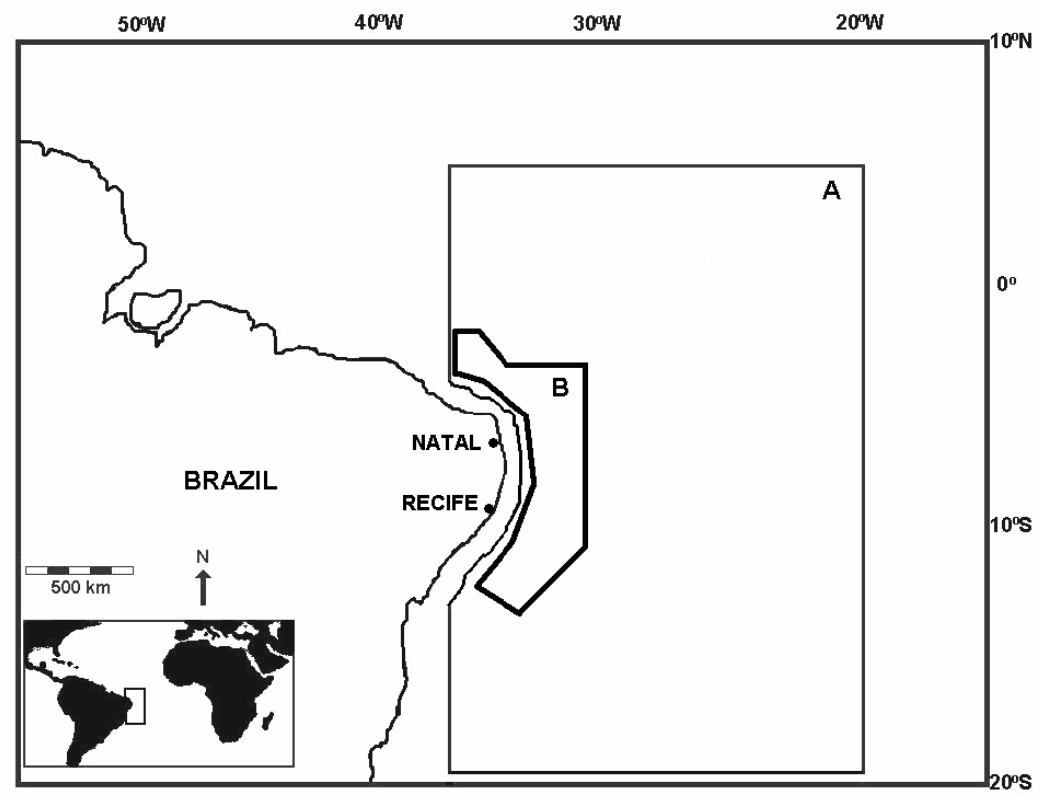

Fig. 1. Sample area in the western tropical Atlantic ocean. A -Area covered by the tuna longliners where stomachs were collected. B - Sampled area by the REVIZEE Program where data of vertical temperature profiles were collected.

Vertical temperature profiles were obtained by CTD (Conductivity, Temperature, Depth, Sensors) from 53 stations on research cruises of the RV "Antares" during the Brazilian REVIZEE Program, between August and October 1995 (Fig. 1).

\section{Results}

Of the 291 individuals analyzed, it was possible to obtain the fork lengths of 193 bigeye tuna, ranging from 60 to $195 \mathrm{~cm}$ (Fig. 2).

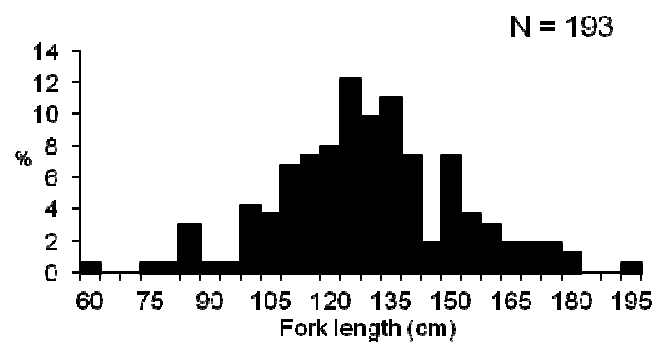

Fig. 2. Length distribution of bigeye tuna in the Western tropical Atlantic ocean.

The number of individuals examined was sufficient to describe the feeding habits of bigeye for this study (Fig. 3). A total of 291 bigeye tuna stomachs were analyzed, in which a total of 83 items were identified, 46 of them being fish, 20 cephalopods, 13 crustaceans, one pteropod, one gastropod, one sea bird, and one tunicate (Table 1). According to the IRI ranking, with the exception of unidentified Teleostei and Cephalopods, the fish Brama caribbea was the most important food item in the diet, followed by other fish such as Alepisaurus ferox, Omosudis lowei, Gempylus serpens, Brama brama, and Diretmus argenteus. The squid Ornithoteuthis antillarum was the only cephalopod among the ten main food items, and Caridea and Brachyuran megalopae were the most representative items of the crustaceans.

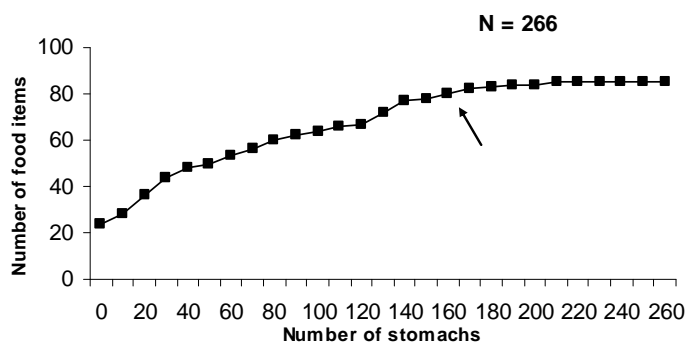

Fig. 3. Diversity of food items in the stomachs of Thunnus obesus in the Western tropical Atlantic ocean. Arrow indicates stabilization. 
Table 1. Food items of bigeye tuna with respective occurrences, percentages, and classification of the most important food items. $\mathrm{N}$ - number of prey; $\mathrm{W}$ - prey weight; FO - frequency of occurrence; $\mathrm{S}$ - non-migrant surface; $\mathrm{M}$ - midwater migrant; $\mathrm{D}$ - non-migrant deep water

\begin{tabular}{|c|c|c|c|c|c|c|c|c|}
\hline \multirow[t]{2}{*}{ Stomachs with food: 266} & \multicolumn{8}{|c|}{ Empty stomachs: 25} \\
\hline & Habitat & $\mathbf{N}$ & $\% \mathbf{N}$ & W & $\% W$ & FO & $\%$ FO & $\begin{array}{c}\text { IRI } \\
\text { ranking }\end{array}$ \\
\hline Acanthurus sp. & Epi & 24 & 0,86 & 23 & 0,05 & 7 & 2,97 & \\
\hline Alepisaurus ferox & Meso & 57 & 2,05 & 7847 & 16,77 & 53 & 22,46 & 3 \\
\hline Antigonia capros & Meso & 3 & 0,11 & 20 & 0,04 & 2 & 0,85 & \\
\hline Antigonia combatia & Meso & 22 & 0,79 & 41 & 0,09 & 10 & 4,24 & \\
\hline Astronestidae & Meso & 1 & 0,04 & 1 & 0,00 & 1 & 0,42 & \\
\hline Avocettina sp. & Meso & 1 & 0,04 & 32 & 0,07 & 1 & 0,42 & \\
\hline Balistidae & Epi & 78 & 2,81 & 283 & 0,60 & 6 & 2,54 & \\
\hline Brama brama & Epimeso & 88 & 3,17 & 882 & 1,88 & 21 & 8,90 & 8 \\
\hline Brama caribbea & Epimeso & 525 & 18,92 & 14784 & 31,59 & 120 & 50,85 & 1 \\
\hline Centropyge aurantonotus & Epi & 1 & 0,04 & & 0,00 & 1 & 0,42 & \\
\hline Chauliodontidae & Meso & 2 & 0,07 & 1 & 0,00 & 1 & 0,42 & \\
\hline Chiasmodontidae & Meso & 40 & 1,44 & 171 & 0,37 & 19 & 8,05 & \\
\hline Coryphaena hippurus & Epi & 2 & 0,07 & 237 & 0,51 & 2 & 0,85 & \\
\hline Cubiceps sp. & Epi & 53 & 1,91 & 702 & 1,50 & 11 & 4,66 & \\
\hline Dactilopyterus volitans & Epi & 148 & 5,33 & 185 & 0,40 & 15 & 6,36 & \\
\hline Diaphus sp. & Meso & 1 & 0,04 & 20 & 0,04 & 1 & 0,42 & \\
\hline Diodon hystrix & Epi & 4 & 0,14 & 84 & 0,18 & 2 & 0,85 & \\
\hline Diodontidae & Epi & 1 & 0,04 & 286 & 0,61 & 1 & 0,42 & \\
\hline Diretmus argenteus & Meso & 66 & 2,38 & 810 & 1,73 & 23 & 9,75 & 10 \\
\hline Exocoetidae & Epi & 1 & 0,04 & 6 & 0,01 & 1 & 0,42 & \\
\hline Gempylus serpens & Meso & 42 & 1,51 & 2595 & 5,54 & 32 & 13,56 & 7 \\
\hline Holocentridae & Epi & 76 & 2,74 & 210 & 0,45 & 14 & 5,93 & \\
\hline Katsuwonus pelamis & Epi & 1 & 0,04 & 339 & 0,72 & 1 & 0,42 & \\
\hline Lestidiops jayakari & Epimeso & 3 & 0,11 & 3 & 0,01 & 3 & 1,27 & \\
\hline Lestidium atlanticum & Epimeso & 14 & 0,50 & 762 & 1,63 & 7 & 2,97 & \\
\hline Lestrolepis intermedia & Epimeso & 1 & 0,04 & 10 & 0,02 & 1 & 0,42 & \\
\hline Myctophidae & Meso & 80 & 2,88 & 429 & 0,92 & 8 & 3,39 & \\
\hline Neolatus tripes & Meso & 6 & 0,22 & 102 & 0,22 & 5 & 2,12 & \\
\hline Nomeidae & Epi & 3 & 0,11 & 44 & 0,09 & 2 & 0,85 & \\
\hline Notosudidae & Meso & 1 & 0,04 & 3 & 0,01 & 1 & 0,42 & \\
\hline Omosudis lowei & Meso & 83 & 2,99 & 3026 & 6,47 & 38 & 16,10 & 6 \\
\hline Ostraciidae & Epi & 28 & 1,01 & 6 & 0,01 & 3 & 1,27 & \\
\hline Paralepididae & Epimeso & 8 & 0,29 & 182 & 0,39 & 6 & 2,54 & \\
\hline Priacanthus sp. & Epi & 2 & 0,07 & 60 & 0,13 & 2 & 0,85 & \\
\hline Ptericombus sp. & Meso & 4 & 0,14 & 130 & 0,28 & 4 & 1,69 & \\
\hline Ruvettus pretiosus & Meso & 3 & 0,11 & 29 & 0,06 & 3 & 1,27 & \\
\hline Scombridae & Epi & 1 & 0,04 & 339 & 0,72 & 1 & 0,42 & \\
\hline Selar crumenophtalmus & Epi & 1 & 0,04 & 14 & 0,03 & 1 & 0,42 & \\
\hline Sternoptyx diaphana & Meso & 8 & 0,29 & 41 & 0,09 & 4 & 1,69 & \\
\hline Stomiidae & Meso & 1 & 0,04 & 300 & 0,64 & 1 & 0,42 & \\
\hline Sudis atrox & Meso & 2 & 0,07 & 35 & 0,07 & 1 & 0,42 & \\
\hline Synagrops sp. & Meso & 47 & 1,69 & 424 & 0,91 & 23 & 9,75 & \\
\hline Teleostei & Epimeso & 110 & 3,96 & 6566 & 14,03 & 73 & 30,93 & 2 \\
\hline Thunnus sp. & Epi & 1 & 0,04 & 45 & 0,10 & 1 & 0,42 & \\
\hline Trachichthidae & Meso & 7 & 0,25 & 138 & 0,29 & 3 & 1,27 & \\
\hline Trachipterus arawatae & Epimeso & 3 & 0,11 & 156 & 0,33 & 3 & 1,27 & \\
\hline Fishes & & 1660 & 59,82 & 36010 & 76,94 & & & \\
\hline Chiroteuthis sp. & Meso & 13 & 0,47 & 180 & 0,38 & 8 & 3,39 & \\
\hline Cranchiidae & Meso & 40 & 1,44 & 733 & 1,57 & 14 & 5,93 & 5 \\
\hline Enoploteuthidae & Epimeso & 28 & 1,01 & 96 & 0,21 & 15 & 6,36 & \\
\hline Enoploteuthis leptura & Epimeso & 31 & 1,12 & 529 & 1,13 & 18 & 7,63 & \\
\hline Histioteuthis sp. & Epimeso & 12 & 0,43 & 104 & 0,22 & 5 & 2,12 & \\
\hline
\end{tabular}


Table 1. Continuation.

\begin{tabular}{|c|c|c|c|c|c|c|c|c|}
\hline \multirow{2}{*}{$\begin{array}{l}\text { Stomachs with food: } 266 \\
\text { Prey types }\end{array}$} & \multicolumn{8}{|c|}{ Empty stomachs: 25} \\
\hline & Habitat & $\mathbf{N}$ & $\% \mathbf{N}$ & W & $\% \mathbf{W}$ & FO & $\%$ FO & $\begin{array}{c}\text { IRI } \\
\text { ranking }\end{array}$ \\
\hline Hyaloteuthis pelagica & Epimeso & 2 & 0,07 & 41 & 0,09 & 2 & 0,85 & \\
\hline Japettela diaphana & Epimeso & 1 & 0,04 & 9 & 0,02 & 1 & 0,42 & \\
\hline Ommastrephes bartramii & Epimeso & 51 & 1,84 & 437 & 0,93 & 13 & 5,51 & \\
\hline Ommastrephidae & Epimeso & 46 & 1,66 & 173 & 0,37 & 13 & 5,51 & \\
\hline Onychoteuthis sp. & Epimeso & 5 & 0,18 & 82 & 0,18 & 3 & 1,27 & \\
\hline Onykia sp. & Epimeso & 8 & 0,29 & 84 & 0,18 & 8 & 3,39 & \\
\hline Ornithoteuthis antillarum & Epimeso & 141 & 5,08 & 910 & 1,94 & 41 & 17,37 & \\
\hline Sthenoteuthis pteropus & Epimeso & 8 & 0,29 & 529 & 1,13 & 7 & 2,97 & \\
\hline Thysanoteuthis rombus & Epimeso & 8 & 0,29 & 90 & 0,19 & 6 & 2,54 & \\
\hline With muscular mass & & 381 & 13,73 & 3817 & 8,16 & & & \\
\hline \multicolumn{9}{|l|}{ Ancistrocheirus lesueuri } \\
\hline Brachioteuthis sp. (beak) & Epimeso & 2 & 0,07 & & & 2 & 0,85 & \\
\hline Cranchiidae (beak) & Epimeso & 1 & 0,04 & & & 1 & 0,42 & \\
\hline Enoploteuthidae (beak) & Epimeso & 2 & 0,07 & & & 1 & 0,42 & \\
\hline Enoploteuthis leptura (beak) & Epimeso & 9 & 0,32 & & & 2 & 0,85 & \\
\hline Histioteuthis sp (beak) & Epimeso & 4 & 0,14 & & & 4 & 1,69 & \\
\hline Japettella diaphoma (beak) & Epimeso & 12 & 0,43 & & & 9 & 3,81 & \\
\hline Octopoteuthis sp. (beak) & Epimeso & 3 & 0,11 & & & 3 & 1,27 & \\
\hline Ocythoe tuberculata (beak) & Epimeso & 3 & 0,11 & & & 3 & 1,27 & \\
\hline Ommastrephidae (beak) & Epimeso & 1 & 0,04 & & & 1 & 0,42 & \\
\hline Onychoteuthidae (beak) & Epimeso & 19 & 0,68 & & & 14 & 5,93 & \\
\hline \multicolumn{9}{|l|}{ Sthenoteuthis pteropus } \\
\hline (beak) & Epimeso & 5 & 0,18 & & & 8 & 3,39 & \\
\hline Taonius pavo (beak) & Epimeso & 1 & 0,04 & & & 1 & 0,42 & \\
\hline \multicolumn{9}{|l|}{ Thysanoteuthis rombus } \\
\hline \multicolumn{9}{|l|}{ Vampyroteuthis infernalis } \\
\hline (beak) & Meso & 2 & 0,07 & & & 2 & 0,85 & \\
\hline Only beaks & & 111 & 4,00 & & & & & \\
\hline \multicolumn{2}{|l|}{ CEPHALOPODS } & 505 & 18,20 & 3997 & 8,54 & & & \\
\hline Food items & & $\mathbf{N}$ & $\% \mathbf{N}$ & $\mathbf{W}$ & $\% W$ & FO & $\%$ FO & $\begin{array}{c}\text { IRI } \\
\text { ranking }\end{array}$ \\
\hline Brachyscelus crusculum & Epi & 16 & 0,58 & 11 & 0,02 & 10 & 4,24 & \\
\hline Brachyura megalopae & Epi & 157 & 5,66 & 168 & 0,36 & 20 & 8,47 & 9 \\
\hline Caridea & Epi & 187 & 6,74 & 67 & 0,14 & 43 & 18,22 & 4 \\
\hline Euphausiacea & Epi & 15 & 0,54 & 14 & 0,03 & 8 & 3,39 & \\
\hline Hemithyphis sp. & Epi & 5 & 0,18 & 28 & 0,06 & 5 & 2,12 & \\
\hline Isopoda & Epi & 12 & 0,43 & 30 & 0,06 & 3 & 1,27 & \\
\hline Nephropidae & Epi & 1 & 0,04 & 2 & & 1 & 0,42 & \\
\hline Penaeidae & Epi & 244 & 8,79 & 56 & 0,12 & 10 & 4,24 & \\
\hline Phronima sedentaria & & 1 & 0,04 & 1 & & 1 & 0,42 & \\
\hline Phrosina semilunata & Epi & 47 & 1,69 & 6 & 0,01 & 4 & 1,69 & \\
\hline Scyllaridae phylossome & Epi & 6 & 0,22 & 2 & & 4 & 1,69 & \\
\hline Stomatopoda & Epi & 3 & 0,11 & 2 & & 2 & 0,85 & \\
\hline Synaxidae & Epi & 15 & 0,54 & 14 & 0,03 & 1 & 0,42 & \\
\hline CRUSTACEANS & & 709 & 25,55 & 401 & 0,86 & & & \\
\hline Gastropoda & Epi & 3 & 0,11 & & & 1 & 0,42 & \\
\hline Pteropoda & Epi & 2 & 0,07 & & & 2 & 0,85 & \\
\hline Puffinus gravis (feathers) & Epi & 1 & 0,04 & & & 1 & 0,42 & \\
\hline Tunicata & Epi & 2 & 0,07 & 1 & & 1 & 0,42 & \\
\hline OTHERS & & 8 & 0,29 & 1 & & & & \\
\hline BAIT & & 47 & 1,69 & 3347 & 7,15 & 47 & 19,92 & \\
\hline TOTAL & & 2933 & & 50149 & & & & \\
\hline TOTAL WITHOUT BAITS & OR BEAKS & 2775 & 100,00 & 46802 & 100,00 & & & \\
\hline
\end{tabular}


Bigeye tuna fed mainly upon fishes and cephalopods that migrate between epi and mesopelagic layers. A total of 36 taxa $(41.8 \%)$ were identified as mid-water migrants (17 fishes, 17 cephalopods and 2 crustaceans), 19 taxa (22.1\%) were representative of deep-water non-migrants (11 fishes, 2 cephalopods), and 31 taxa $(36.1 \%)$ were surface-water non-migrants (17 fishes, 10 crustaceans, one pteropod, one gastropod, one bird and one tunicate). A general view of the distribution of the main prey items, based on Legand et al. (1972), Bowman and Gruner (1973) and Roper and Young (1975), and the vertical range distribution of bigeye tuna (DAGORN et al., 2000; MUSYL et al., 2003), is shown in relation to the thermocline profile recorded for the equatorial Atlantic inside the sampled area (Fig. 4). With the exception of the juveniles of Gempylus serpens, all the others representative fishes in the ten main food items were mid and deep water fishes (B. caribbea, A. ferox, $O$. lowei, B. brama, and D. argenteus). Although not important as main prey items in the IRI ranking, a remarkably high abundance was observed of the fishes Dactylopterus volitans (148), Balistidae (78), Holocentridae (76), Acanthurus sp. (24) and Ostraciidae (28), considered as brephoepipelagic fishes, i. e., fishes that live in the epipelagic zone when juveniles $(2-8 \mathrm{~cm})$ but settle down in coastal waters when adults. Various kinds of bait were present in $17.7 \%$ of the total stomachs analyzed.

Prey length ranged between 1 and $110 \mathrm{~cm}$ in body length, although most prey items were situated between 1 and $20 \mathrm{~cm}$, with a mean size of $12.5 \mathrm{~cm}$ (Fig. 5). All prey items larger than $60 \mathrm{~cm}$ were of the mesopelagic fish Alepisaurus ferox.

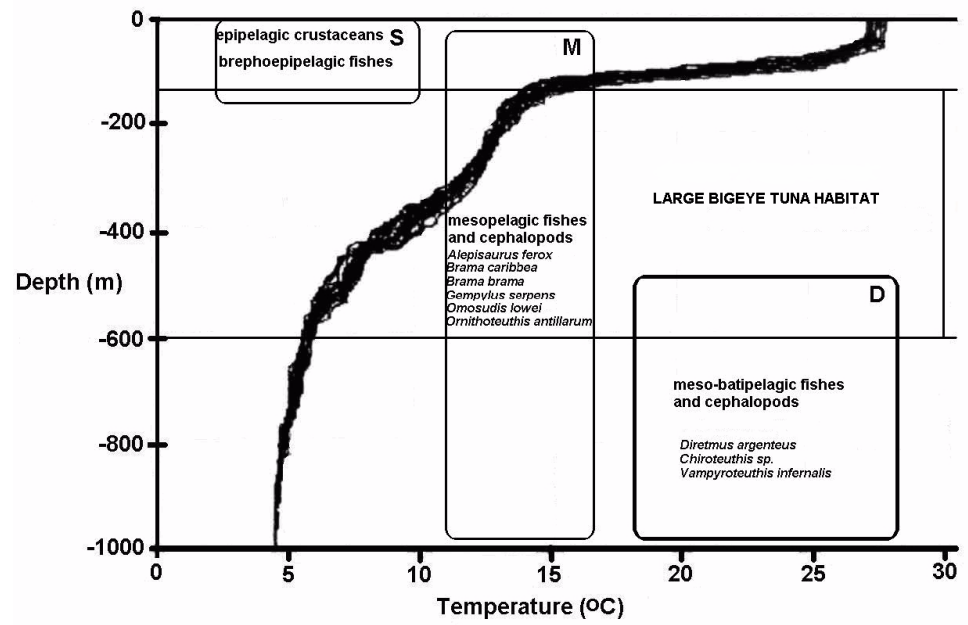

Fig. 4. Accumulated thermocline profiles from Western tropical Atlantic ocean, and bigeye tuna preferential habitat with their main representative prey organisms. $\mathrm{S}-$ non-migrant surface; $\mathrm{M}$ - midwater migrants; D - non-migrant deep water.

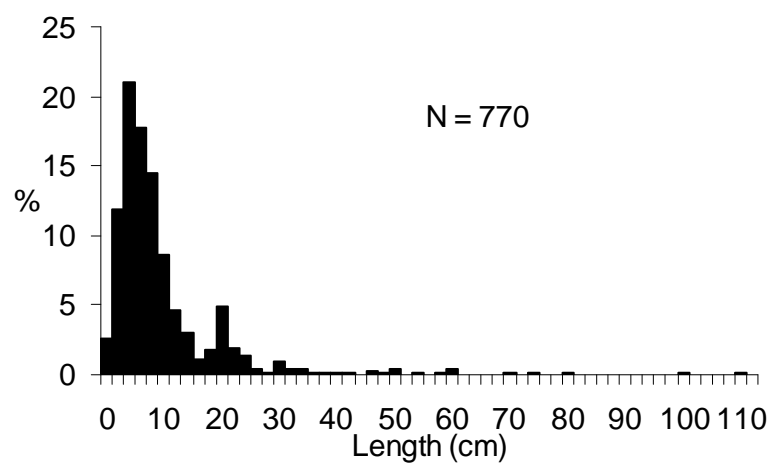

Fig. 5. Prey lengths distribution for bigeye tuna. 
The degrees of stomach fullness were $5.15 \%$ empty, $36.67 \%$ of $25 \%$ full, $28.86 \%$ of $50 \%$ full, $23.36 \%$ of $75 \%$ full, and $8.93 \%$ of full stomachs, which means that the bigeye tuna maintains a constant amount of food in the stomach, chiefly at levels of between $25 \%$ and $75 \%$.

\section{DISCUSSION}

The bigeye tuna fork lengths observed in this study were close to $130 \mathrm{~cm}$ the range usually reported for specimens caught by longline, in the Atlantic Ocean. Travassos (pers. communic.), for instance, reported that the fork length of bigeye tuna caught by longline in the western tropical Atlantic, between 1965 and 1993, ranged from 65 to $190 \mathrm{~cm}$, with a mode in the 130-cm class, while Zavala-Camin (pers. communic.), about 30 years ago, reported lengths between 56 and $194 \mathrm{~cm}$, from specimens caught off Southwestern Brazil $\left(23^{\circ} \mathrm{S}\right.$ to $\left.32^{\circ} \mathrm{S}\right)$. Since the bigeye tuna reaches sexual maturity at $113.5 \mathrm{~cm}$ FL for females and $112.4 \mathrm{~cm}$ for males (Figueiredo, pers. communc.) most of the individuals analyzed were probably adult specimens.

Many environmental factors are likely to have significant effects on the vertical distribution of a pelagic fish such as the bigeye tuna, but temperature, dissolved oxygen and prey have an important role in the process (BACH et al., 2003; POTIER et al., 2007). In the present study, food items were represented by organisms found from near the surface to deep waters, which means that bigeye tuna fed upon a wide diversity of food items in the water column. Moteki et al. (2001) pointed out that $93.1 \%$ of the prey items of bigeye tuna in the tropical Pacific Ocean belong to the mid-water group of organisms, which is represented mainly by sternoptychids, myctophids, bramids, omosudids and paralepidids.

Bigeye tuna also come to the layers above the thermocline to feed on small crustaceans and fishes, although their higher captures are made on deeper longline hooks, usually located below the thermocline (DAGORN et al., 2000). The relatively equal proportions of surface, mid-water and deepwater prey organisms reflect the species' behavior of constant displacement in the water column in search of prey.

The time of feeding is difficult to determine from passive gear like the longline, due to the long permanence of the gear in the water (approximately 812 hs). Nevertheless, due to the evidence of the constant presence of food in the stomachs, there is little possibility of a periodical feeding time for bigeye tuna during the 24-hour cycle. Thus, feeding must be continuous or take place at least during the greater part of the day or night. This might be a consequence of the relatively small-sized stomachs that do not need a great amount of food to fill them, which may be Figures 5 and 6, which may be part of the effect of the feeding strategy on the characteristics of food spectra, i.e., a wide, scattered and small prey distribution in the pelagic environment of oligotrophic regions such as the equatorial/tropical oceans. So it is possible that prey organisms are not organized in patches but are dispersed, which would explain the high diversity of feeding items found. If it can be assumed that the bigeye tuna searches constantly for food, we may suppose that the individuals of each prey species are distributed randomly, at low density, within the foraging area of the predator.

The ten main prey items (Table 1) have a vertical distribution consistent with the vertical behavior of bigeye tuna, and their abundance in the stomachs may reflect the higher abundance of this kind of prey in layers between 150 and $600 \mathrm{~m}$. All crustaceans and minor groups (pteropods, gastropods and tunicates) are commonly dwellers in the epipelagial zone. All the cephalopods identified in the present study undertake extensive vertical migrations throughout the day and night, occupying both the epi and mesopelagic environments, with the exceptions of adult Cranchiidae, Chiroteuthis sp. and Vampyroteuthis infernalis which are dwellers of the inferior mesopelagic environment (500-1000 m). The high abundance of the brephoepipelagic fishes has also been observed in the feeding habits of the other pelagic predators in the same area such as dolphinfish, Coryphaena hippurus (VASKE JR. ; LESSA, 2004), istiophorids (VASKE JR. et al., 2004) and swordfish, Xiphias gladius (VASKE JR.; LESSA, 2005). The very wide distribution and abundance of brephoepipelagic fishes indicate that they are an important food resource not only for the epipelagic predators in the area but also for the bigeye tuna, although the preference is for migrant and deep-water organisms. Despite the well-known high biomass of myctophids in the mesopelagic environment throughout the oceans, the myctophids preyed on by bigeye tuna in the present study did not constituted an important prey. Based on the arguments hypothesized by Bertrand et al. (2002), myctophids are too deeply distributed to represent a profitable prey for bigeye tuna. Dense Myctophidae layers were detected between 350 and $750 \mathrm{~m}$ in the same oceanic area as that of the REVIZEE Program by the RV "Atlântico Sul" during acoustic and mid-water trawl surveys in 2005 (MADUREIRA et al., 2005). The energy of Myctophidae may be transferred to micronekton and then to bigeye tuna as has been observed in the diet of Brama caribbea that is the main micronektonic fish preyed on by bigeye tuna in the IRI ranking, in which myctophids are one of the main prey items (VASKE JR. et al., 2008). 
Bigeye tuna differ from other tunas and billfishes by virtue of the ecological implications of their vertical movement patterns, which allow them to find prey at greater depths. Brill et al. (2005) have summarized the results of studies that attempt to explain the greater vertical displacement capacity of bigeye tuna as a function of their better vascular counter-current heat exchangers, better heart rate and cardiac output following acute reductions in ambient temperature, better tolerance of sharp reductions in ambient oxygen, and greater visual range due to the movement of the lens and photoreceptor topography. These characteristics enable the bigeye tuna to adapt to dim light conditions, strongly suggesting that visual acuity and tolerance to low temperature and oxygen levels play an important role in the species' preying upon migrant and deep-dwelling organisms. It is recommended that in future studies of the bigeye tuna, research should also investigate: seasonal sampling, for both sexes; the depth of the hooks on which the fish are captured, and the prey weight according to the different layers in the water column, to make a more precise definition of the species' preferential habitats possible.

\section{AcKowledgements}

The authors are grateful to the observers of the Observers on Board National Program (PROBORDO) of the Secretaria Especial de Agricultura e Pesca (SEAP), who collected the stomachs on board the tuna longliners, and to the DEPAq-UFRPE laboratories where the samples were analyzed.

\section{REFERENCES}

BACH, P.; DAGORN, L.; BERTRAND A.; JOSSE, E.; MISSELIS, C. Acoustic telemetry versus monitoring longline fishing for studying the vertical distribution of pelagic fish: bigeye tuna (Thunnus obesus) in French Polynesia. Fish. Res., v. 60, p. 281-292, 2003.

BERTRAND, A.; JOSSE, E.; BACH, P.; GROS, P.; DAGORN, L. Hydrological and trophic characteristics of tuna habitat: consequences on tuna distribution and longline catchability. Can. J. Fish. aquat. Sci., v. 59, p. 1002-1013. 2002.

BOWMAN, T. E.; GRUNER, H. E. The families and genera of Hyperiidea (Crustacea: Amphipoda). Smithson. Contrib. Zool., n. 146, 64 p., 1973.

BRILL, R. W.; BLOCK, B. A.; BOGGS, C. H.; BIGELOW K. A.; FREUND, E. V.; MARCINEK, D. J. Horizontal movements and depth distribution of large adult yellowfin tuna (Thunnus albacares) near the Hawaiian Islands, recorded using ultrasonic telemetry: implications for the physiological ecology of pelagic fishes. Mar. Biol., v.133: p. 395-408, 1999.

BRILL, R. W.; BIGELOW, K. A.; MUSYL, M. K.; FRITSCHES, K. A.; WARRANT, E. J. Bigeye tuna (Thunnus obesus), behaviour and physiology and their relevance to the stock, assessment and fishery biology. Col. Vol. Sci. Pap. ICCAT v. 57, n. 2, p.142-161, 2005.

COLLETTE, B. B.; NAUEN, C. E. FAO Species catalogue. Vol. 2. Scombrids of the World. An annotated and illustrated catalogue of tunas, mackerels, bonitos and related species known to date. FAO Fish. Synop., 125 p., 1983.

CORTÉS, E. A critical review of methods of studying fish feeding based on analysis of stomach contents: application to elasmobranch fishes. Can. J. Fish. aquat. Sci., v. 54, p. 726-738, 1997.

DAGORN, L.; BACH, P.; JOSSE, E. Movement patterns of large bigeye tuna (Thunnus obesus) in the open ocean, determined using ultrasonic telemetry. Mar. Biol., v. 136, p. 361-371, 2000.

DRAGOVICH, A. Review of studies of tuna food in the Atlantic Ocean. Bureau of Commerce of Fishery, Tropical Atlantic Biological Laboratory, US Fish and Wildlife Service., Spec. Sci. Rep. Fish. v. 593, n. 117, 21p. 1969.

EVANGELISTA, J. V.; OLIVEIRA, G. M.; VASCONCELOS, J. A. Evolução da pesca de atuns no nordeste do Brasil. Bolm téc.-cient. CEPENE, v. 6, n. 1, p. 77-108, 1998

HAZIN, F. H. V.; ZAGAGLIA, J. R.; BROADURST, M. K.; TRAVASSOS, P. E. P.; BEZERRA T. R. Q. Review of a small-scale pelagic longline fishery of northeastern Brazil. Mar. Fish. Rev. v. 60, n. 3, p. 1-8. 1998.

HOLLAND, K. N.; BRILL, R. W.; CHANG, R.; SIBERT, J.; FOURNIER, D. Physiological and behavioural thermoregulation in bigeye tuna (Thunnus obesus). Nature v. 358 , p. $410-412,1992$.

ICCAT. International Commission for the Conservation of Atlantic Tunas. Report of the Standing Committee on Research and Statistics (SCRS), Spain 2006.

LEE, P. F.; CHEN, I C.; TZENG, W. N. Spatial and temporal distribution patterns of bigeye tuna (Thunnus obesus) in the Indian Ocean. Zool. Stud., v. 44, n. 2, p. 260-270. 2005.

LEGAND, M.; BOURRET, P.; FOURMANOIR, P.; GRANDPERRIN, R.; GUEREDRAT, J. A.; MICHEL, A.; RANCUREL, P.; REPELIN, R.; ROGER, C. Relations trophiques et distributions verticales en milieu pélagique dans L'océan Pacifique Intertropical. Cah. ORSTOM, sér. Océanogr., v. 10, n. 4, p. 303-393. 1972.

MADUREIRA, L. S. P.; HABIAGA, R.; DUVOISIN, A. C.; WEIGERT, S. C.; FERREIRA, C. S.; PINHO, M. P. Prospecção hidroacústica sobre a plataforma e o talude da ZEE do nordeste do Brasil, no Arquipélago de São Pedro e São Paulo e nos Bancos Oceânicos do Ceará. (Programa REVIZEE). Relatório Final LTP-DOC-FURG. 2005. 79 $\mathrm{p}$

MATTHEWS, F. D.; DAMKAER, D. M.; KNAPP, L. W.; COLLETTE, B. B. Food of western North Atlantic tunas (Thunnus) and lancetfishes (Alepisaurus). NOAA Tech. Rep., NMFS SSRF-706, 19 p., 1977. 19 p.

MOTEKI, M.; ARAI, M.; TSUCHIYA, K.; OKAMOTO, H. Composition of piscine prey in the diet of large pelagic fish in the eastern tropical Pacific Ocean. Fish. Sci. v. 67, p.1063-1074. 2001.

MUSYL, M. K.; BRILL, R. W.; BOGGS, C. H.; CURRAN, D. S.; KAZAMA, T. K.; SEKI, M. P. Vertical movements of bigeye tuna (Thunnus obesus) associated with islands, buoys, and seamounts near the main Hawaiian Islands from archival tagging data. Fish. Oceanogr. v. 12, p.152-169, 2003 
PINKAS, L.; OLIPHANT, M. S.; IVERSON, I. L. K. Food habits of albacore, bluefin tuna, and bonito in Californian waters. Fish. Bull. v. 152.105 p. 1971

POTIER, M.; MARSAC, F.; CHEREL, Y.; LUCAS, V.; SABATIÉ, R.; OLIVIER, M; MÉNARD, F. Forage fauna in the diet of three large pelagic fishes (lancetfish, swordfish and yellowfin tuna) in the western equatorial Indian Ocean. Fish. Res., v. 83, p. 60-72, 2007.

ROPER, C. F. E.; YOUNG, R. E. Vertical distribution of pelagic cephalopods. Smithson. Contr. Zool., v 209, p.1$51,1975$.

SMITH, M. M.; HEEMSTRA, P. C. Smith's sea fishes. Berlin: Springer Verlag, 1986. $1047 \mathrm{p}$.

VASKE JR., T.; LESSA, R. P. Feeding habits of the common dolphinfish (Coryphaena hippurus), in the Northeastern Brazilian Exclusive Economic Zone. Arq. Ciênc. Mar., v. 37, p.131-138, 2004.

VASKE JR., T.; LESSA, R. P. Estratégia alimentar do espadarte, Xiphias gladius, no nordeste do Brasil. Tropic. Oceanogr., v. 33, n. 2, p. 219-217, 2005.

VASKE, JR., T.; RINCÓN, FO. G. Conteúdo estomacal dos tubarões azul (Prionace glauca) e anequim (Isurus oxyrinchus) em águas oceânicas no sul do Brasil. Rev. Bras. Biol., v. 58, n. 3, p. 443-450, 1998.
VASKE JR., T.; VOOREN, C. M.; LESSA, R. P. Feeding habits of four species of Istiophoridae (Pisces: Perciformes) from northeastern Brazil. Environ. Biol. Fish., v. 70, p. 293-304, 2004.

VASKE JR., T.; LESSA, R. P.; BARBOSA, T. M.; TRAVASSOS, M. T.; RIBEIRO, A. C. B. Stomach contents of the Caribbean pomfret Brama caribbea (Mead, 1972) from stomach contents of great pelagic predators from Southwestern equatorial Atlantic. Bolm. Inst. Pesca, S. Paulo, v. 34, n. 2, p. 241-249, 2008.

ZAVALA-CAMIN, L. A. Distribución del patudo (Thunnus obesus) em el sudeste y sur del Brasil (1969-1977). Bolm. Inst. Pesca, S. Paulo, v. 5, n. 1, p.40-50, 1978.

(Manuscript received 05 March 2010; revised 14 April 2011; accepted 07 October 2011) 